\title{
Basement Configuration from Magnetotelluric Studies in Bhuj Earthquake Epicentral Zone, Gujarat, India
}

\author{
S. Kareemunnisa Begum ${ }^{*}$, T. Harinarayana ${ }^{2}$ \\ ${ }^{1}$ Department of Geophysics, Andhra University, Visakhapatnam, India \\ ${ }^{2}$ Gujarat Energy Research and Management Institute, Gandhinagar, India \\ Email: "skbegum.geophy@auvsp.edu.in
}

Received 6 April 2016; accepted 27 August 2016; published 30 August 2016

Copyright (C) 2016 by authors and Scientific Research Publishing Inc.

This work is licensed under the Creative Commons Attribution International License (CC BY). http://creativecommons.org/licenses/by/4.0/

(c) (i) Open Access

\section{Abstract}

A wide band (1000 - $0.001 \mathrm{~Hz})$ magnetotelluric study has been taken up in the Bhuj earthquake epicentral zone and 21 sites have been occupied along three profiles during March-April 2001 to understand the deep structure of the region. In addition the region surrounding Bhuj has been probed earlier with number of MT profiles and the subsurface structure is well constrained from hydrocarbon exploration point of view besides seismotectonic studies. In the present study, the results obtained along $130 \mathrm{~km}$ long profile from Mundra to Rapar oriented in NE-SW direction passing through the epicenter are presented considering these two databases. The subsurface structure has shown interesting correlation with the surface deformations, a new basement configuration and associated seismotectonics of the region. Our main result is relating the basement configuration and surface ruptures.

\section{Keywords}

Bhuj, Magnetotellurics, Earthquake, Surface Ruptures, Tectonics, Gujarat

\section{Introduction}

Basement mapping is important to understand the subsurface structural features in a sedimentary basin, which in turn pave a way for better insight of the tectonics. To study the seismotectonics of a region, it is a prerequisite to understand the physical processes related to seismicity in general, and more so in earthquake epicentral zones. The recent devastating Bhuj earthquake ( $M$ 7.9) of $26^{\text {th }}$ Jan., 2001, a rare event over the past 50 years, has killed

${ }^{*}$ Corresponding author.

How to cite this paper: Begum, S.K. and Harinarayana, T. (2016) Basement Configuration from Magnetotelluric Studies in Bhuj Earthquake Epicentral Zone, Gujarat, India. Open Journal of Earthquake Research, 5, 177-188. 
more than 20,000 people. Several geophysical and geological investigations have been carried out immediately after the earthquake to understand the seismicity of the region (Gupta et al., 2001 [1]; Kayal et al., 2002 [11]; Kareemunnisa Begum, 2003 [2], Sastry et al., 2008 [3]; Naganjaneyulu et al., 2010 [4]). To understand the basement features and also to study the deep crustal structure in the region, a wide band $(1000-0.001 \mathrm{~Hz}) \mathrm{mag}$ netotelluric study has been taken up in the Bhuj earthquake epicentral zone (Kareemunnisa Begum, 2003 [2]).

The subsurface structure mapped earlier in the region is well constrained from gravity, deep seismics, deep electrical and magnetotelluric studies geophysical methods (Harinarayana et al., 2000 [5]). These results gave an evidence for increase in thickness of sediments to as large as $3-4 \mathrm{~km}$ from north to south with sharp change in thickness near geological faults. Although these studies have provided valuable information about the deep structure, the present magnetotelluric study was initiated with more number of stations along 3 profiles near the earthquake epicentral zone. These profiles are oriented one along N-S profile i.e. Mundra-Kavda profile and one along E-W profile i.e. Kodi-Manaba profile not shown in Figure 1 and another along NE-SW profile from Mundra to Rapar pass through the well-known structural features such as Katrol Fault, Kutch Mainland Fault (KMF), South Wagad Fault and also the reported epicentre near Bachau. The MT results discussed in the present study are along a long NE-SW profile from Mundra to Rapar. This profile forms part of the earlier as well as recent studies and is shown along with the regional tectonic map of the Kutch region (Figure 1) (Ref. [2]).

\section{Data}

The data consists of the natural electric and magnetic fields of the earth measured using wide band (1000 - 0.001 $\mathrm{Hz}$ ) digital magnetotelluric data acquisition system (GMS05, Germany). A dipole length of $80-100 \mathrm{~m}$ has been used for telluric field measurements (Ex and Ey). Three component magnetic fields ( $\mathrm{Hx}, \mathrm{Hy}$ and $\mathrm{Hz}$ ) were measured using induction coil magnetometers. The entire system is computer controlled with on-line processing to monitor the data and the processed results for quality check. The data were acquired for on an average of about 1 to 2 days. The frequency range of signals are large enough to scan the earth from shallow to deeper levels (5 to $10 \mathrm{~km}$ and more), although the resistivity of shallow layers is very low, of the order of 1 to 10 Ohm?m.

The data acquired have been evaluated for its quality by visually inspecting the time series on a screen. The bad data segments i.e. the data corrupted by spikes as well as from $50 \mathrm{~Hz}$ electrical noise are deselected before

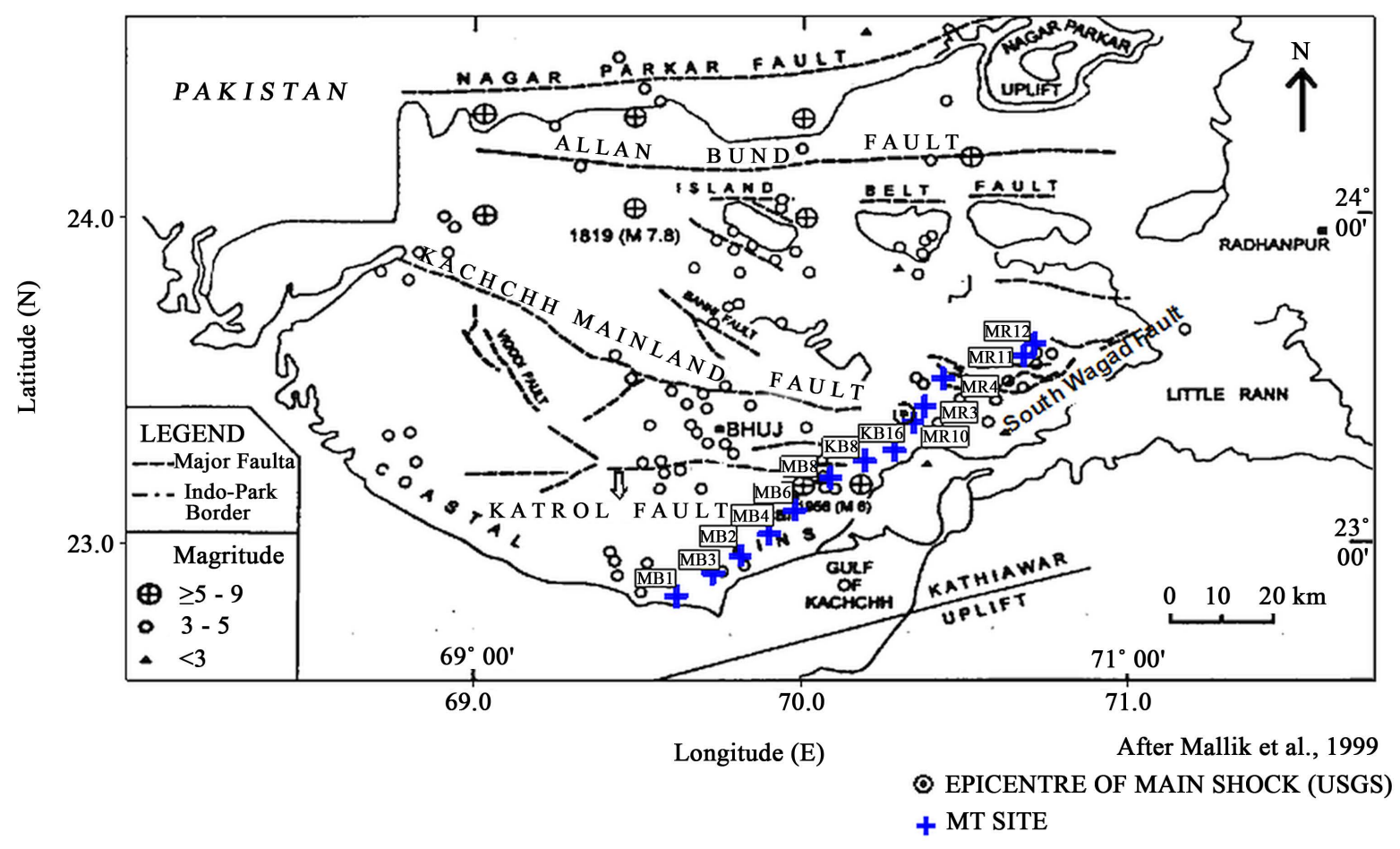

Figure 1. Location map of MT sites near Bhuj earthquake epicentral region, India along with regional tectonics. 
further processing. A linear trend removal for each data window is carried out by fitting a straight line using trend removal technique. The time series data converted into frequency domain and complex Fourier spectra, auto and cross spectra of five components Ex, Ey, Hx, Hy and Hz, the MT parameters such as impedance, apparent resistivity, phase, coherency, skew etc., are obtained by normal processing procedures using weighted coherency criteria. The procedure is repeated for all sessions of data and a final set of smoothed spectra are obtained for each site.

A consistent regional strike for the data set is obtained from the plot of (Swift 1967 [6]) swift angle for all the sites. Towards the longer period the average strike angle of about $\mathrm{N} 45^{\circ} \mathrm{E}$ is obtained and thus regional strike direction is considered as $\mathrm{N}^{\circ} 5^{\circ} \mathrm{W}$ with $90^{\circ}$ ambiguity. From the tectonic map (Figure 1) of the Kutch region the eastern half is fully dominated by nearly EW oriented geological faults. However, in the western half of Kutch, the fault (KMF) orientation is nearly $\mathrm{N} 45^{\circ} \mathrm{W}$. This is consistent with the regional strike direction $\mathrm{N} 45^{\circ} \mathrm{W}$ obtained in our study (Figure 2). To deal with the galvanic distortion and to reduce the effect of local inhomogeneties, the Groom-Bailey tensor decomposition method is applied for all sites (Groom and Bailey, 1989 [7]). The data is also corrected for static shift based on the geology of the local area. The profile from Mundra to Rapar crosses different geological formations ranging from Recent to Jurassic. The sites falling on each formation are grouped together and the apparent resistivity values obtained after Groom-Bailey Decomposition in both XY and YX components averaged at $100 \mathrm{~Hz}$ and the resultant value is assigned to the individual Rho-XY and RhoYX components. In Figure 3 the apparent resistivity values before and after static shift correction are shown for $100 \mathrm{~Hz}$ frequency. The apparent resistivity so resulted is considered for modeling.

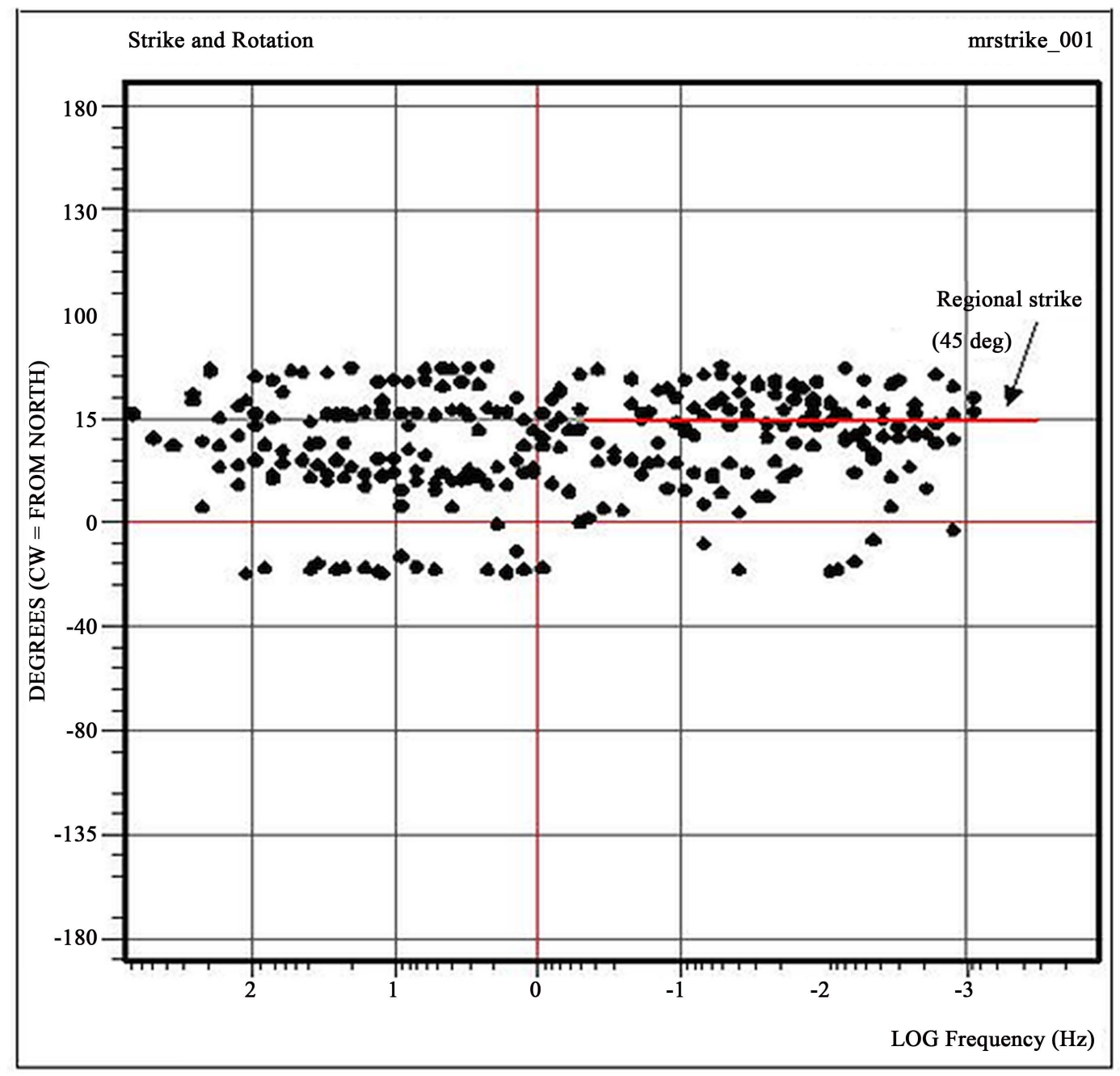

Figure 2. Data showing strike direction (Swift angle) for all sites indicating regional strike as $45^{\circ}$. 

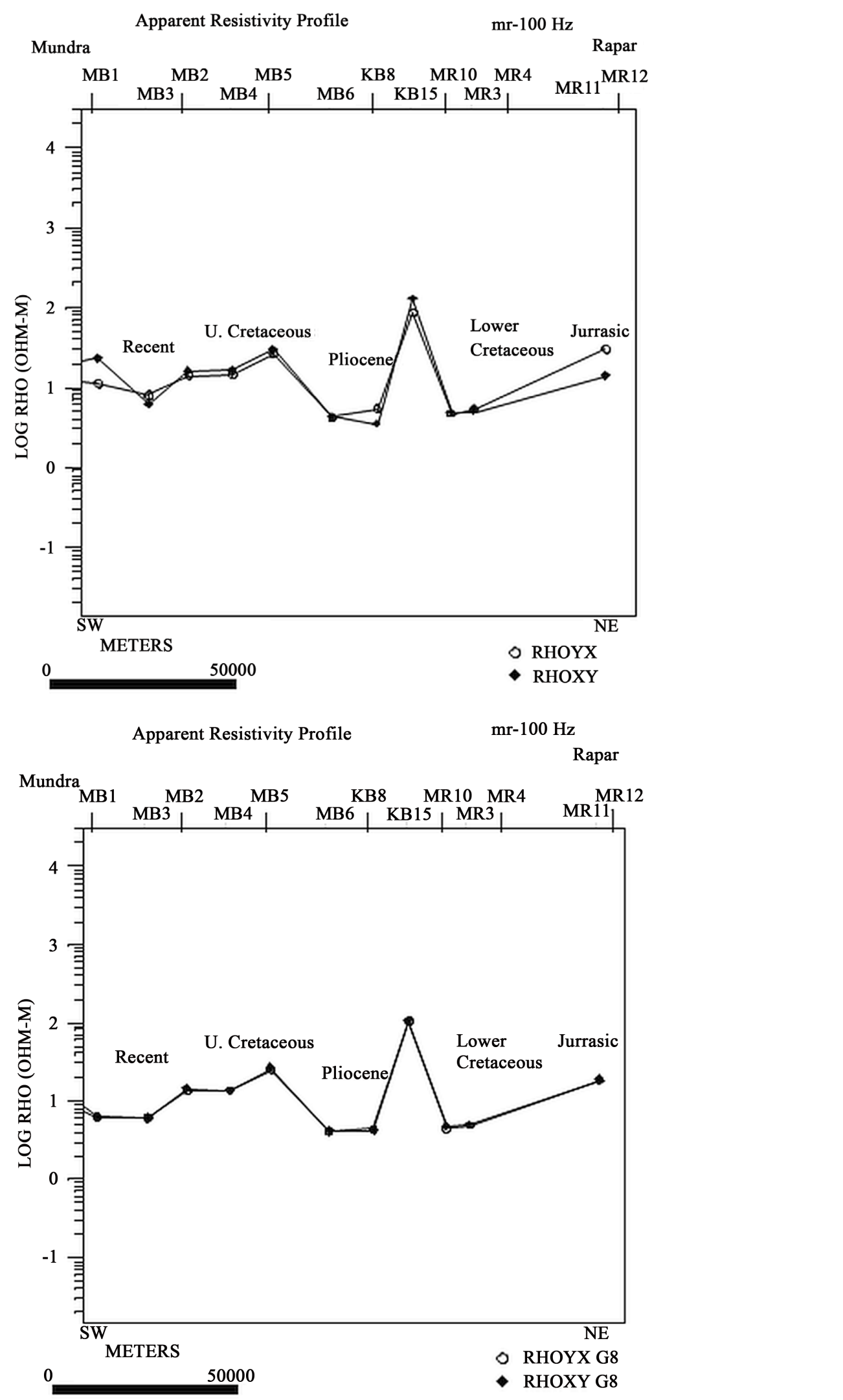

Figure 3. GB decomposed apparent resistivity in XY and YX directions at $100 \mathrm{~Hz}$ before and after static shift correction. 


\section{Modeling}

The MT sounding curves are shown in Figure 4(a) and Figure 4(b) for the sites KB8 and MR12. The station KB8 is towards the south of KMF. The apparent resistivity value starts with $5 \mathrm{Ohm} \cdot \mathrm{m}$ in the higher frequencies and increased to $\sim 20 \mathrm{Ohm} \cdot \mathrm{m}$ at $2 \mathrm{~Hz}$. This shows that the conductive recent formation is underlain by resistive formation at shallow depth. At this location the alluvium is underlain by resistive Deccan traps. The apparent resistivity reduces to $6 \mathrm{Ohm} \cdot \mathrm{m}$ at $10 \mathrm{Sec}$. indicating a thick layer of sediment indicative of Bhuj formation and again increases and reaches to $100 \mathrm{Ohm} \cdot \mathrm{m}$ towards lower frequency indicating resistive basement. In the case of MR12, located towards north of KMF it can be seen that the curve exhibits a near horizontal pattern upto about $5 \mathrm{~Hz}$ and then increases gradually with a gentle gradient. This shows that the sediments are lying directly over the resistive basement.

Another qualitative study is the analysis of apparent resistivity pseudosection. Such a qualitative study is very important to formulate a meaningful model using inversion techniques. In Figure 5 apparent resistivity pseudosections along Mundra-Rapar profile is shown. Towards the high frequency end large lateral variations of apparent resistivity is seen and towards the low frequency there is a gradual variation of apparent resistivity as we proceed from south-west to north-east. The large variation of high frequency data could be due to the presence of various sedimentary formations. The apparent resistivity (about $20 \mathrm{Ohm} \cdot \mathrm{m}$ ) (shown in green colour) is seen below $0.01 \mathrm{~Hz}$ towards the south-west end of the profile is continuing towards north to higher frequency $0.5 \mathrm{~Hz}$. This indicates that high resistivity at subsurface depths is deeper towards the south when compared to north. This is correlatable with the phase data also.

Magnetotelluric data is modeled initially by using direct transformation techniques in order to obtain semiquantitative estimates and then followed by 1-D modeling techniques using inversion schemes. While various transformation techniques are available Bostick transformation scheme is used h (Bostick, 1977 [8]). After obtaining the semi-quantitative information from the data, 1-D modeling using linearized inversion schemes (Marquardt, 1963 [9]; Constable et al., 1987 [10]) are carried out. As an example Bostick transformation obtained for stations KB8, MB3, MR12 and MB6 are presented in Figure 6 for rotationally invariant rho-determinant data. The resistivity of the shallow layers is about $20 \mathrm{Ohm} \cdot \mathrm{m}$ to a depth of $500 \mathrm{~m}$ followed by more conductive sediments $(7-8 \mathrm{Ohm} \cdot \mathrm{m})$. These formations are underlain by more resistive formation representing the basement feature extending to deep crustal depths as shown in figure. The data has been subjected to linear inversion schemes and the combined results of subsurface structure along the profile is shown in Figure 7 . The basement depth is around $5 \mathrm{~km}$ at Mundra towards southwest end of the profile and becomes shallow towards north $(1-1.5 \mathrm{Km})$ near Rapar. The basement topography although gentle, exhibits undulations at places along the profile. These undulations near the Katrol fault, Kutch Mainland Fault and South Wagad Fault are quite evident.

\section{Discussion}

Several geological and geophysical studies have been carried out in and around Bhuj earthquake epicentral region soon after the Bhuj earthquake of 2001. Earlier to these studies the region has been covered by detailed gravity, deep seismic, deep resistivity and also magnetotellurics (Gupta et al., 2001 [1]) as a part of integrated geophysical study for hydrocarbon exploration. These studies have provided valuable information about the sub-surface structure. Subsurface electrical structure is an important input to understand the seismotectonics of the region particularly in the seismically active areas. Low resistivity zone has been reported by several workers (Unsworth et al., 1997 [12], 1999 [13]) in the vicinity of active faults. The role of crustal fluid in the generation of earthquakes have given importance (Gupta et al., 1996 [14], Zhao et al., 1996 [15]) in recent times. Keeping in view of the above MT has been initiated in and around the epicentral zone in order to obtain more details about the subsurface structure that can throw more light to understand the seismotectonics of the region. Also the present study we have tried to examine the geoelectric section upto $5 \mathrm{~km}$.

In a special section on Bhuj earthquake some of the geological studies of Bhuj region have been complied (Karanth et al., 2001 [16], Ravi Sankar \& Pande 2001 [17],). They are briefly described in the following. The studies from Karanth et al., 2001 [16] have identified large-scale ground fissuring, lateral spreads/faulting, rock falls and slumping, liquefaction and fluidization. Most of the intense liquefaction and ground-rupture sites fall along the extent of Kutch Mainland Fault (KMF). This has given an indication that a part of KMF may have been activated. The resistivity study (Singh et al., 2001 [18]) carried out in the epicentral region delineated 

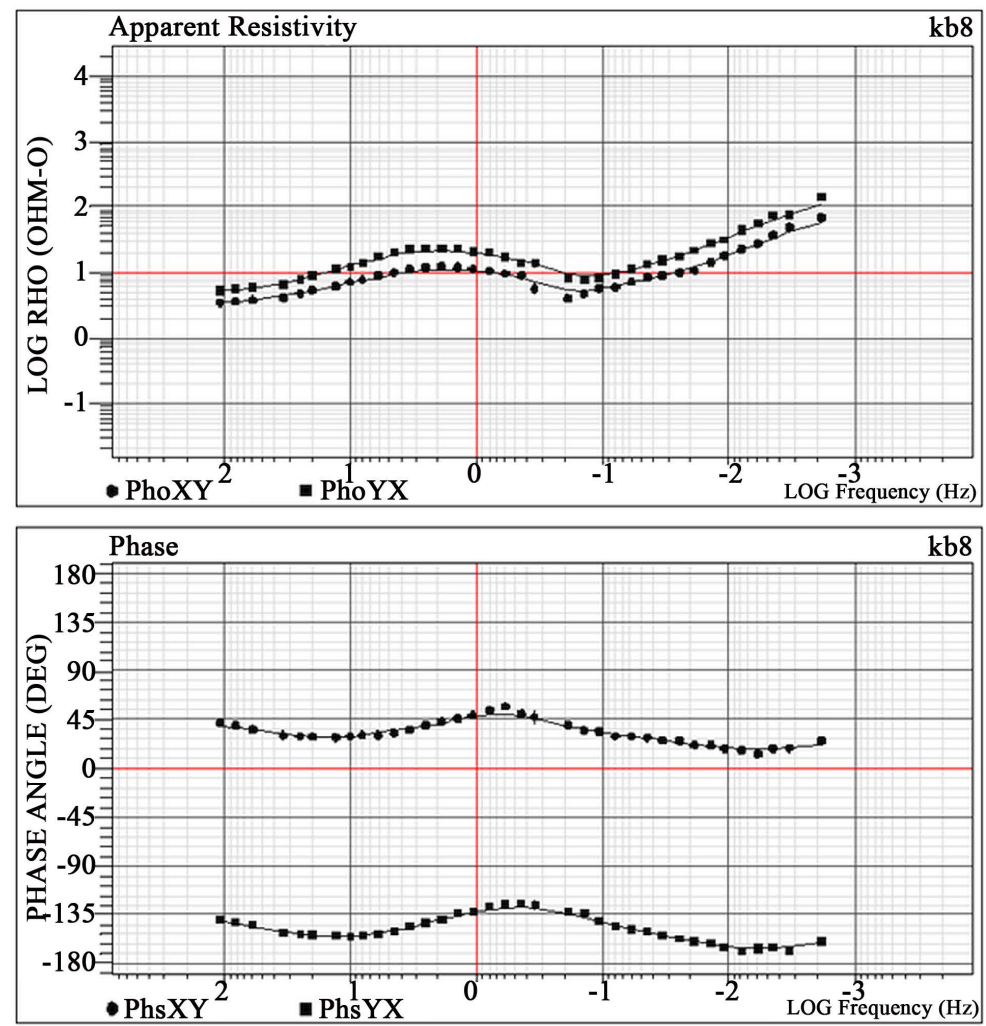

(a)
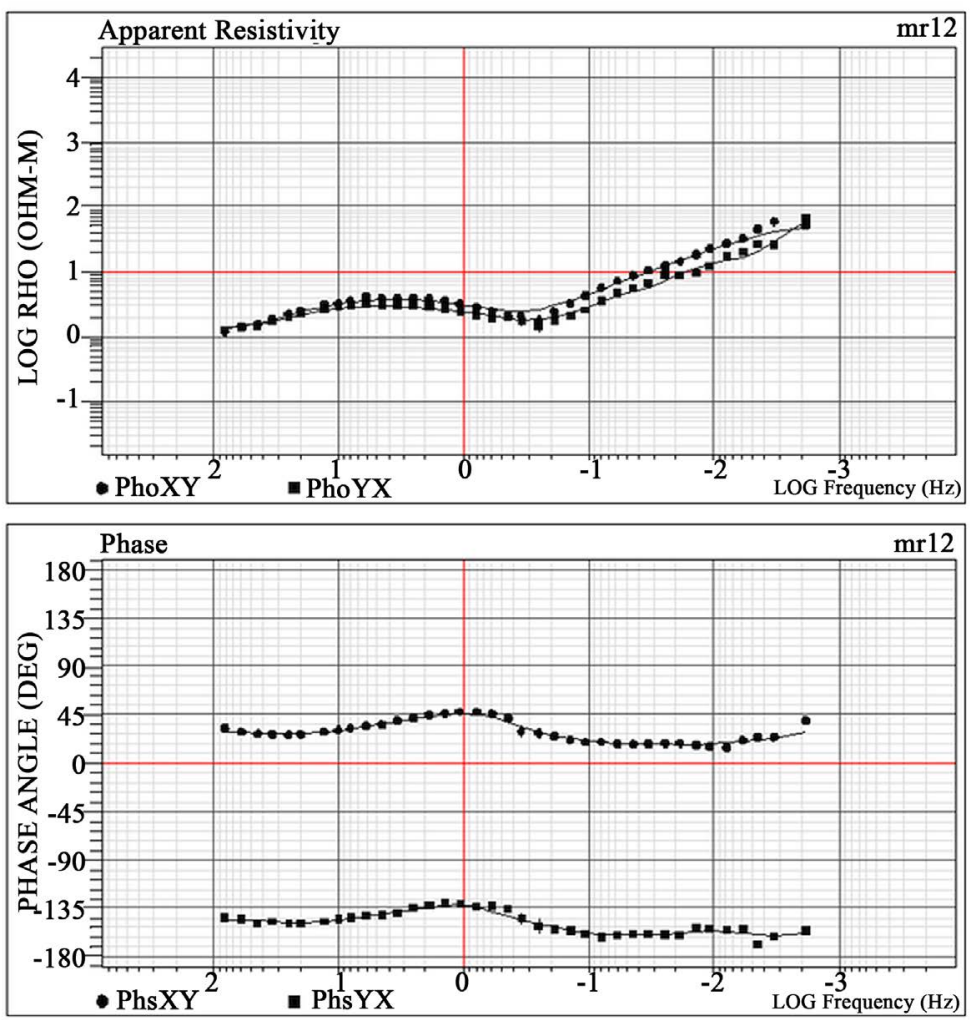

(b)

Figure 4. MT sounding curves for two stations (a) KB8 and (b) MR12. 

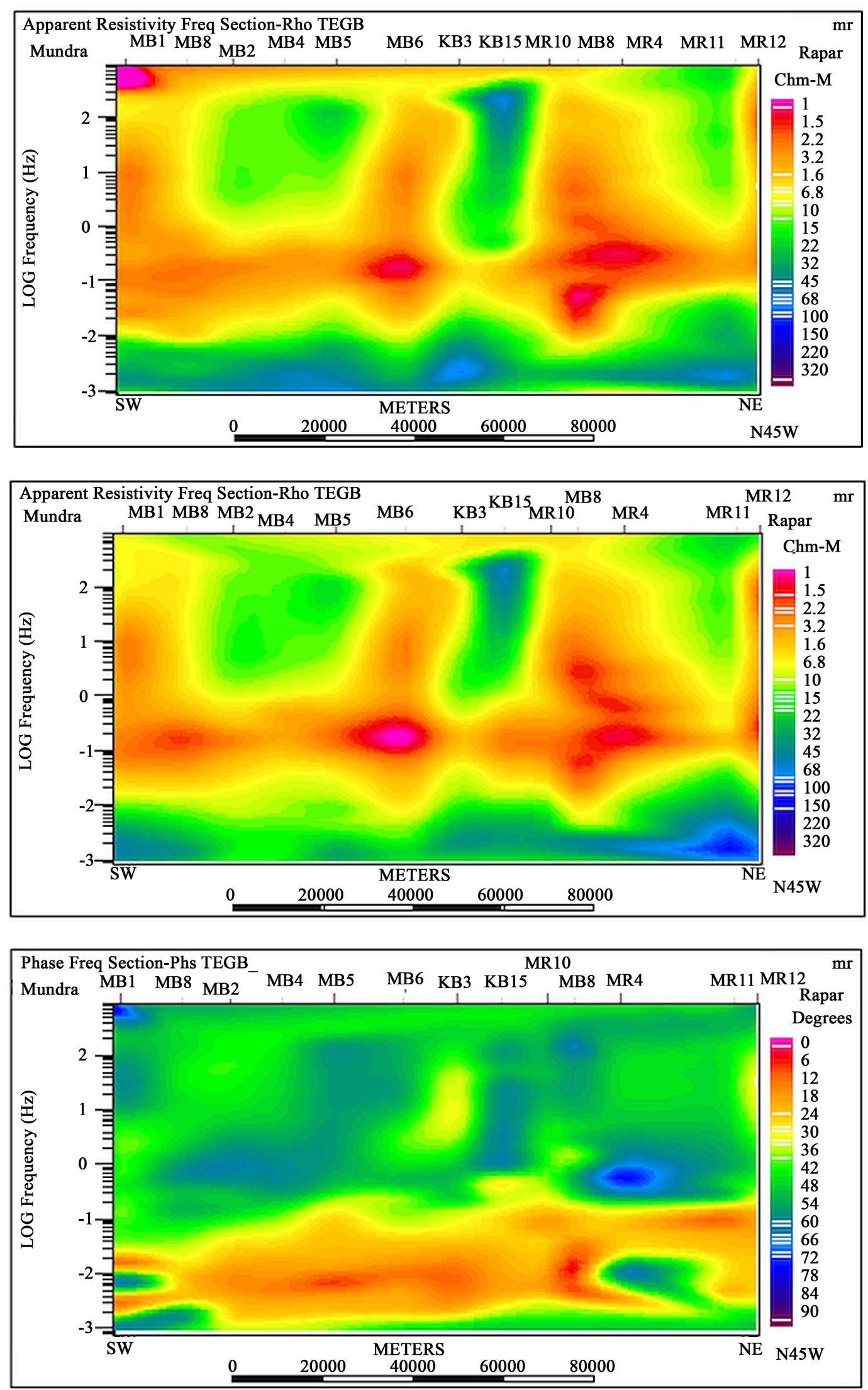


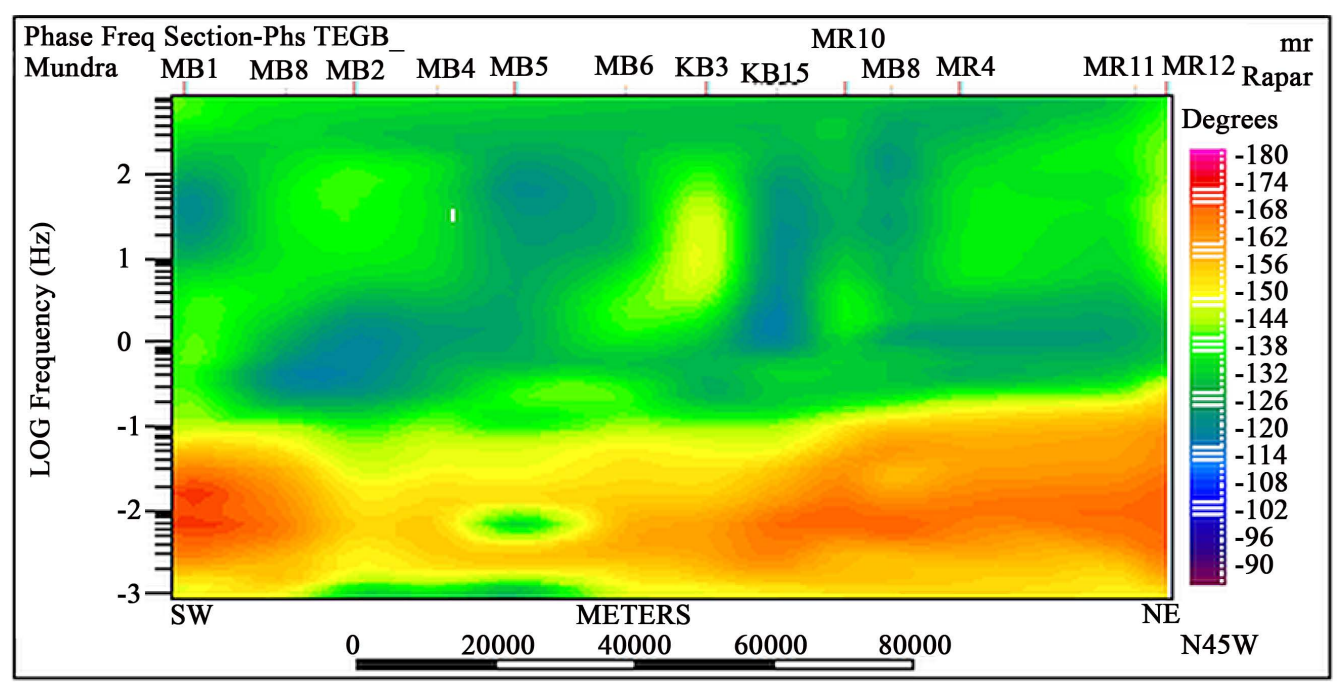

Figure 5. Apparent resistivity-frequency pseudo section and phase-frequency pseudo section along the profile.
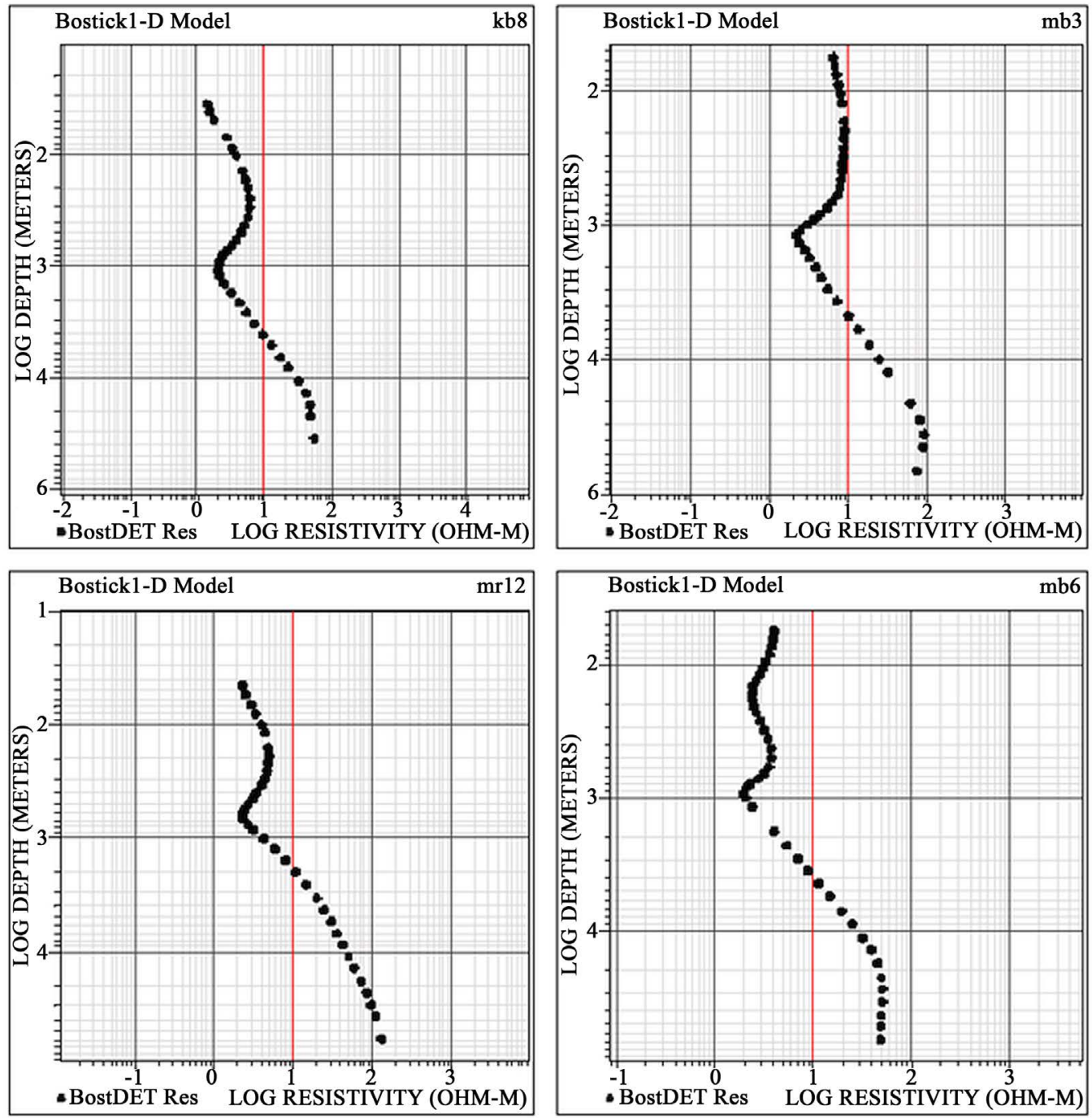

Figure 6. Bostick 1D model for the stations KB8, MB3, MR12 and MB6. 
SOUTH WAGAD FAULT ZONE

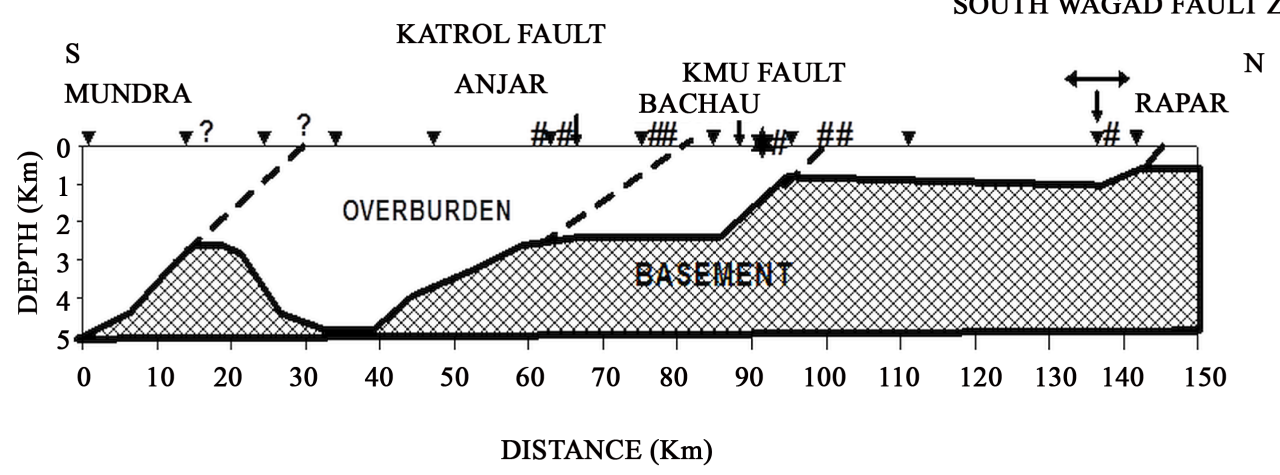

\section{+ EPICENTRE \\ $\checkmark$ MTSTATION}

\# SURFACE FISSURES (Karanth et al., 2001)

Figure 7. Subsurface section from Magnetotelluric data along the profile.

shallow low resistivity layer particularly in the liquefaction sites. Further, Singh et al., 2001 [18] reported that intense liquefaction has been observed to a distance of around $250 \mathrm{~km}$ from the epicentral region which led to numerous surface cracks and fissures.

The fault propagation pattern of the Bhuj earthquake shows that the energy is released in the region along the existing faults and the epicentral location of Bhuj earthquake lies very near to the Kutch mainland fault (Paul and Kamal, 2001 [19]) and indicates that KMF may have relation to the earthquake. Isoseismals suggested that the main rupture might have occurred along a deep-seated fault following the Delhi-Aravalli trend parallel to Jamnagar-Chambal mega lineament (Ravi Shankar, 2001 [20]).

(Naik 2001 [21]) studied the land deformation in parts of Gujarat and observed that deformation has occurred in the form of soil rupture, landslides, and lateral spread in the soils, soil slumping, and craters. Several soil ruptures east of Bhuj, land slides at many places along the fault/fracture zones weakening the terrain further have been reported by (Naik 2001 [21]). The liquefaction induced by Bhuj earthquake has been studied in detail by (Pande et al., 2001 [22]). They reported that the sandy places of Rann of Kutch and little Rann, as well as the Banniland and Bet Islets, the water at shallow depths provided the most conductive environment for liquefaction. However, the liquefaction was violent at places of coseismic tectonic displacement apart from strong and prolonged shaking (Pande et al., 2001 [22]). Seed 1970 [23] also explained the occurrence of soil liquefaction is due to the building up of pore pressure during the process of compaction induced by earthquake vibrations in soils with appropriate grain size and degree of water saturation. Bouguer anomaly map (Mishra et al. 2001 [24]) suggested that the instability in the epicentral area of Bhuj earthquake is because of vertical uplift. Sarkar et al., 2001 [25] estimated the regions where pore pressure due to compression have increased and decreased in response to undrained stress changes induced by Bhuj earthquake. The study of strong motion records of Bhuj earthquake (Kumar et al., 2001 [26]) shows a peak in the ground acceleration at Anjar. Geomagnetic depth sounding and long period magnetotelluric studies (Arora et al., 2001 [27]) delineated a conductive layer at 10 $17 \mathrm{~km}$ depths.

While these studies have provided valuable information to understand the seismicity of the region, it is quite interesting to note from the present study that a steep basement undulation is observed below Anjar and also along the profile from Mundra to Rapar. An interesting correlation is that the surface fissures/ruptures reported recently (Karanth et al., 2001) are located in the vicinity of basement undulations. In such a scenario, one can examine the role of basement undulations and surface fissures.

From close examination of the surface deformation mapped by (Karanth et al., 2001 [16]) and the basement undulations mapped from the present study seems to be spatially correlated to each other. Such an interesting correlation can be explained by a tectonic model as shown in Figure 8. The figure shows a cartoon depicting the development of zone of weakness near the fault plane and also near the basement undulation. It is well known that tectonic forces on Indian plate are acting from south to north. These force also acts on the sediments located towards south. These sedimentary formations have to move over the undulating hard rock (basement) located 

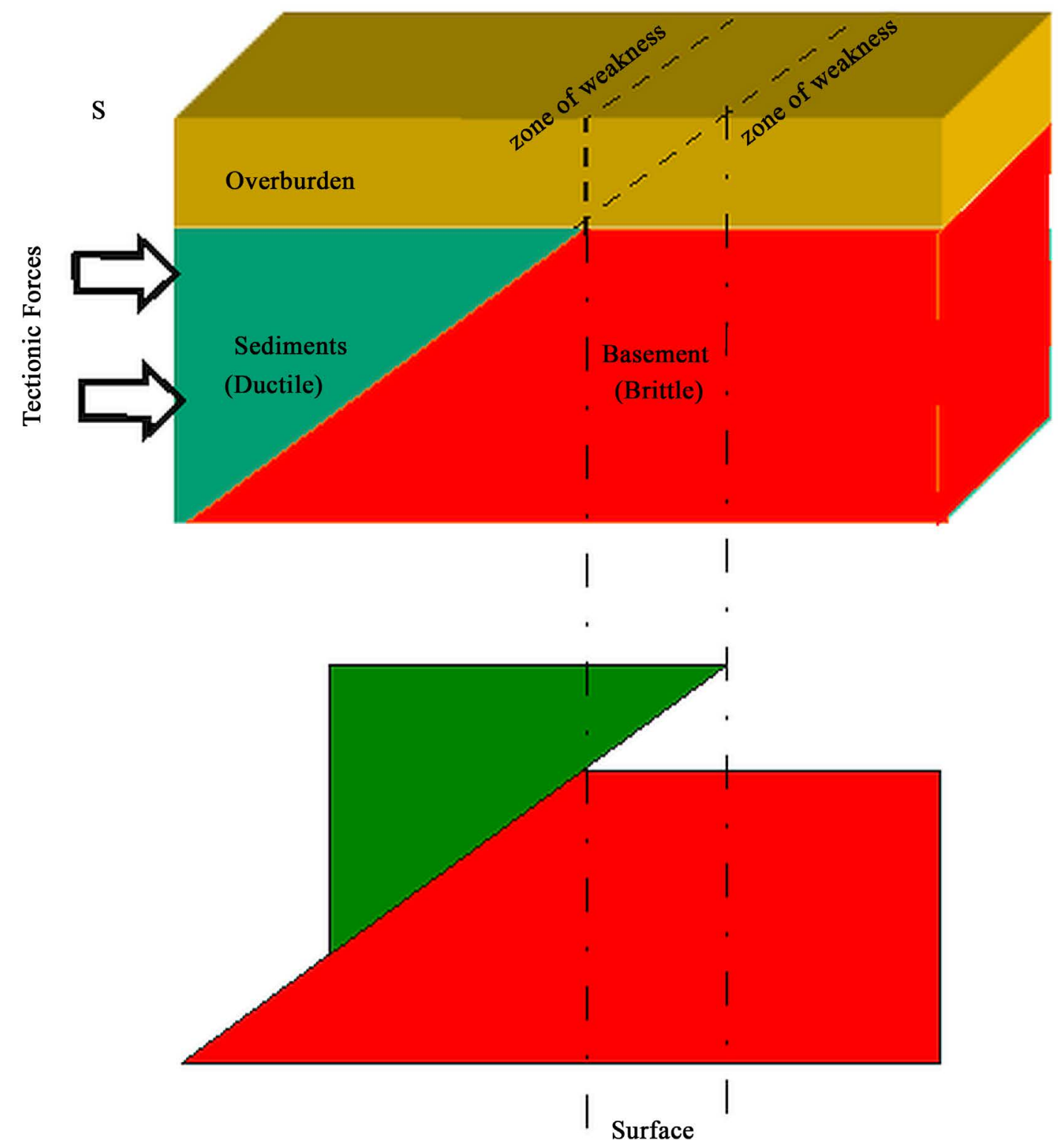

Fissu

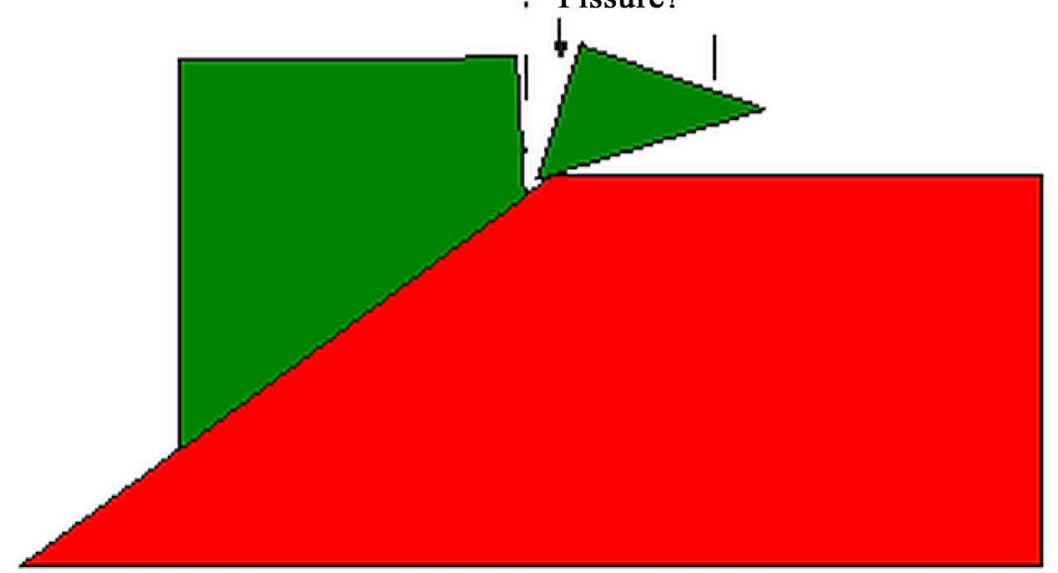

Figure 8. Schematic diagram depicting the zone of weakness near the fault plane and also near the basement undulation. 
towards north. Since forces acting from south direction on the sediments towards north is continuous for a long duration, then over a period of geological time the rock loses its strength and may break at places as shown in Figure 8. This might be the reason for development of surface deformation only at specific locations. These locations, observed directly over the basement undulation and also along the well mapped geological faults is significant as the faults are known to be as weak zones.

\section{Concluding Remarks}

The subsurface geoelectrical structure is investigated in the present study using magnetotellurics near Bhuj earthquake epicentral zone. The results obtained along a long traverse are presented considering the magnetotellurics studies and also from earlier integrated geophysical studies. The subsurface structure has shown a marked variation of the resistive basement with sharp change in the basement depths at a few locations. The basement depth is shallow towards north from 0.5 to $1 \mathrm{~km}$ and deepens to as large as $5 \mathrm{~km}$ towards the southern part of the profile near Mundra located near the coast. From the examination of the surface deformations mapped at several locations around the epicentral zone and the basement undulations from the present study an interesting correlation is observed. This has been explained considering the tectonic forces acting on the weak sedimentary formations while the hard rock basement is relatively stable.

\section{Acknowledgements}

We thank the Director NGRI for all his encouragement and permission to publish this work. Co-operation and help rendered during data acquisition and processing by Mr. Abdul Aziz K.K., Mr. Prasanth, Mr. Ravi Kumar is acknowledged. The author Ms. S.K.Begum wish to thank CSIR for providing fellowship towards her research work at NGRI.

\section{References}

[1] Gupta, H.K., Harinaryana, T., Kousalya, M., Mishra, D.C., Mohan, I., Rao, N.P., Raju, P.S., Rastogi, B.K., Reddy, P.R. and Sarkar, D. (2001) Bhuj Earthquake of 26 January 2001. Journal of the Geological Society of India, 57, 275-278.

[2] Kareemunnisa Begum, S. (2003) Deep Geoelectric Structure in Chamoli and Bhuj Earthquake Epicentral Zones, India Using Magnetotelluric Studies. Ph.D. Thesis, Osmania University, 1-260.

[3] Sastry, R.S., Nagarajan, N. and Sarma, S.V.S. (2008) Electrical Imaging of Deep Crustal Features of Kutch, India. Geophysical Journal International, 172, 934-944. http://dx.doi.org/10.1111/j.1365-246X.2007.03658.X

[4] Naganjayneyulu, K., Ledo, J.J. and Queralt, P. (2010) Deep Crustal Electromagnetic Structure of Bhuj Earthquake Region (India) and Its Implications. Geologica Acta, 8, 83-97.

[5] Harinarayana, T., Sastry, R.S., Nagarajan, N., Prabhakar, S., Rao, E., Manoj, C., Naganjaneyulu, K., Murthy, D.N. and Sarma, S.V.S. (2000) Integrated Geophysical Studies for Hydrocarbon Exploration, Kutch, India. Magnetotellurics, NGRI Technical Report No. NGRI-2000-Exp-296.

[6] Swift, C.M. (1967) A Magnetotelluric Investigation of an Electrical Conductivity Anomaly in the South Western United States. Unpublished Ph.D. Thesis, Department of Geology and Geophysics, Massachusetts Institute of Technology, Cambridge.

[7] Groom, R.W. and Bailey, R.C. (1989) Analytical Investigations of the Effects of Near-Surface Three Dimensional Galvanic Scatterers on MT Tensor Decompositions. Geophysics, 56, 496-518. http://dx.doi.org/10.1190/1.1443066

[8] Bostick, F.X. (1977) A Simple and Almost Exact Method of MT Analysis (Abstract). Workshop on Electrical Methods in Geothermal Exploration, Snowbird, Utah.

[9] Marquardt, D.W. (1963) An Algorithm for Least-Square Estimation of Non-Linear Parameters. Journal of the Society for Industrial and Applied Mathematics, 11, 431-471. http://dx.doi.org/10.1137/0111030

[10] Constable, S.C., Parker, R.L. and Constable, C.G. (1987) Occam Inversion: A Practical Algorithm for Generating Smooth Models from EM Sounding Data. Geophysics, 92, 289-300. http://dx.doi.org/10.1190/1.1442303

[11] Kayal, J.R., De, R., Ram, S., Sriram, B.V. and Goankar, S. (2002) Aftershocks of the 26 January, 2001 Bhuj Earthquake in Western India and Its Seismotectonic Implications. Journal of the Geological Society of India, 59, 395-417.

[12] Unsworth, M.J., Malin, P.E., Egbert, G.D. and Booker, J.R. (1997) Internal Structure of the San Andreas Fault Zone at Parkfield, California. Geology, 25, 359-362. http://dx.doi.org/10.1130/0091-7613(1997)025<0359:ISOTSA>2.3.CO;2

[13] Unsworth, M.J., Egbert, G.D. and Booker, J.R. (1999) High Resolution Electromagnetic Imaging of the San Andreas Fault in Central California. Journal of Geophysical Research, 104, 1131-1150. http://dx.doi.org/10.1029/98JB01755 
[14] Gupta, H.K., Sarma, S.V.S., Harinaryana, T. and Virupakshi, G. (1996) Fluids below the Hypocentral Region of Latur Earthquake, India: Geophysical Indicators. Geophysical Research Letters, 23, 1569-1572. http://dx.doi.org/10.1029/96GL01032

[15] Zhao, D., Kanamori, H. and Negishi, H. (1996) Tomography of the Source Area of the 1995 Kobe Earthquake: Evidence for Fluids at the Hypocentre? Science, 274, 1891-1894. http://dx.doi.org/10.1126/science.274.5294.1891

[16] Karanth, R.V., Sohoni, P.S., Mathew, G. and Khadkikar, A.S. (2001) Geological Observations of the 26 January 2001 Bhuj Earthquake. Journal of the Geological Society of India, 58, 193-202.

[17] Sanker, R. and Pande, P. (2001) Geoseismological Studies of Kutch (Bhuj) Earthquake of 26 January 2001. Journal of the Geological Society of India, 58, 203-208.

[18] Singh R.P., Sahoo, A.K., Sanjeeb, B., Kumar, G.M. and Bhuiyan, C. (2001) Ground Deformation of the Gujarat Earthquake of 26 January 2001. Journal of the Geological Society of India, 58, 209-214.

[19] Paul, A. and Kamal (2001) Fault Propagation Pattern of the January 26, 2001 Gujarat Earthquake. International Conference on Seismic Hazard with Particular Reference to Bhuj Earthquake, New Delhi, 26 January 2001, 22.

[20] Sanker, R. (2001) Seismotectonics of Kutch Region and Isoseismals of Kutch (Bhuj) Earthquake of 26 January 2001. International Conference on Seismic Hazard with Particular Reference to Bhuj Earthquake, New Delhi, 26 January 2001, 29.

[21] Naik, S.D (2001) Land Deformation in Parts of Gujarat due to Earthquake of 26 January 2001. International Conference on Seismic Hazard with Particular Reference to Bhuj Earthquake, New Delhi, 26 January 2001, 76-77.

[22] Pande, P., Ghevaria, S.Y.P. and John, B. (2001) Coseismic ground Deformation and Liquefaction Induced by Kutch (Bhuj) Earthquake of 26 January 2001. International Conference on Seismic Hazard with Particular Reference to Bhuj Earthquake, New Delhi, 26 January 2001, 79-80.

[23] Seed, H.B. (1970) In: Wiegel, R.L., Ed., Earthquake Engineering, Prentice Hall Inc., Englewood Cliffs, 227-251.

[24] Mishra, D.C., Chandrasekhar, D.V. and Singh, B. (2001) Bhuj Earthquake of 26 January 2001 and Gravity Gradients/Trends. International Conference on Seismic Hazard with Particular Reference to Bhuj Earthquake, New Delhi, 26 January 2001, 81.

[25] Sarkar, I. and Chandra, R. (2001) On pore pressure changes due to soil liquefaction and undrained poroelastic effects during the 2001 Bhuj earthquake. International Conference on Seismic Hazard with Particular Reference to Bhuj Earthquake, New Delhi, 26 January 2001, 134-139.

[26] Kumar, A., Basu, S., Thakkur, S.K., Shrikhande, M., Agarwal, P., Das, J. and Paul, D.K. (2001) Strong Motion Records of Bhuj Earthquake. International Conference on Seismic Hazard with Particular Reference to Bhuj Earthquake, New Delhi, 26 January 2001, 144-146.

[27] Arora, B.R., Subba Rao, P.B.V., Rawat, G. and Singh, A.K. (2001) Singh, Deep Electrical Conductivity Distribution around the Bhuj Earthquake Affected Region. International Conference on Seismic Hazard with Particular Reference to Bhuj Earthquake, New Delhi, 26 January 2001, 230-231.

\section{Submit or recommend next manuscript to SCIRP and we will provide best service for you:}

Accepting pre-submission inquiries through Email, Facebook, LinkedIn, Twitter, etc.

A wide selection of journals (inclusive of 9 subjects, more than 200 journals)

Providing 24-hour high-quality service

User-friendly online submission system

Fair and swift peer-review system

Efficient typesetting and proofreading procedure

Display of the result of downloads and visits, as well as the number of cited articles

Maximum dissemination of your research work

Submit your manuscript at: http://papersubmission.scirp.org/ 